\title{
DIELECTRIC MEASUREMENTS OF THE TERNARY MIXTURES OF ALCOHOLS WITH ANILINE IN CARBON TETRACHLORIDE AT 301K
}

\author{
S. Aram ${ }^{1}$, H. B. Ramalingam ${ }^{2}$ and P. Krishnamurthi ${ }^{3, *}$ \\ ${ }^{1}$ Department of Physics, Sri G. V. G. Visalakshi College for Women, \\ Udumalpet, Tamilnadu, India \\ ${ }^{2}$ Department of Physics, Government Arts College, Udumalpet, Tamilnadu, India \\ ${ }^{3}$ Department of Physics, Government Arts College, Dharmapuri, Tamilnadu, India \\ *E-mail: drkrishnamurthi@gmail.com
}

\begin{abstract}
The nature of hydroxylamine complexes was identified through the formation of hydrogen bonding between alcohols (methanol, ethanol, propanol, and butanol) with aniline from the dielectric measurements like dielectric constant, density and refractive index. From these measurements, the dipole moment of hydroxylamine complex was determined from the Huysken's method origin of Onsager model also evaluated the dipolar increment. The enthalpy changes due to bond formation obtained from the dipolar increment. The dipole moment of the both cis and trans structure are determined and tabulated, the dipole moment values of the trans are higher than the cis structure it may complex is form the trans structure. The value of dipole moment of the complex, dipolar increment and enthalpy changes concluded complex formation mainly due to the polarization only. These values indicate the order of the complex methanol > ethanol > propanol > butanol, aniline as one of the component.

Keywords: H-bonding, dipole moment, Huyskens, Onsager theory, Dipolar increment, Enthalpy.

(c) RASĀYAN. All rights reserved
\end{abstract}

\section{INTRODUCTION}

Dielectric measurements of the ternary liquid mixtures of alcohol with aniline in carbon tetrachloride give the information regarding the molecular structure, alignment of dipoles, etc., in solution state. ${ }^{1-5}$ The formation of hydrogen bonding between the donor-acceptor complexes, modify the polarity of liquids due increase the dielectric constant, polarization and dipole moment etc. Many authors ${ }^{5-10}$ identified the nature of complexes of alcohols with other acceptor components amine, carbonyl compounds. The characteristics of dipole moment are depending on the polar characteristics of the acid and bases, hence calculated dipole moment of the complex and related parameter. ${ }^{11-15}$ The dipole moment of the amine alcohol complexes are higher than the sum of the dipole moment of amine and alcohol molecules due to the charge rearrangement among the directions of the specific bond. In this paper, investigate the nature of complexes from the dipole moment values of 1:1 complexes of alcohols with aniline also report the results of dipolar increment, enthalpy changes, cis and trans dipole moment for all the ternary liquid mixtures.

\section{EXPERIMENTAL}

The AR grade methanol, ethanol, propanol, butanol, aniline, and carbon tetrachloride were used in present investigation with purity $99.99 \%$ after purification of standard methods. The solutions were prepared by the required amount of solutes mixed with the solvents in using $10 \mathrm{ml}$ volumetric flasks. AR grade carbon tetrachloride was used as solvent throughout all measurements. The dielectric constant was measured using RL09 dipole meter. It is operated in 220 Volts and having frequency $300 \mathrm{KHz}$. The samples were placed in the sample cell, the sample cell is made of the co-axial brass cylinder and the cell was maintained a constant temperature by using a precision thermostat with an accuracy $\pm 0.1^{\circ} \mathrm{C}$. The dipole meters calibrated with help of the standard liquids. The refractive indices and densities were measured 
using Abbe's refractometer and $5 \mathrm{ml}$ specific gravity bottle respectively. The temperatures were maintained at $301 \mathrm{~K}$ through all measurements.

\section{Determination of Dipole moment of 1:1 complex}

Consider the components $\mathrm{A}$ and $\mathrm{B}$ in an inert solvent, the dipole orientation of A and B changes due to the mobilization of the liquid state. Assume that the small duration, the orientation of molecules is constant, the dipole moment can be written as:

$$
\mathrm{D}=\left[\frac{9 \mathrm{KTX} 10^{39}}{4 \pi \mathrm{N}_{\mathrm{a}}}\right] \mathrm{X}\left[\frac{\left(\varepsilon-\mathrm{n}^{2}\right)\left(2 \varepsilon+\mathrm{n}^{2}\right)}{\varepsilon\left(\mathrm{n}^{2}+2\right)^{2}}\right]-\frac{\mathrm{C}_{\mathrm{S}}}{\mathrm{C}_{\mathrm{s}}^{\mathrm{o}}}\left[\frac{\left(\varepsilon_{\mathrm{s}}-\mathrm{n}_{\mathrm{s}}^{2}\right)\left(2 \varepsilon+\mathrm{n}_{\mathrm{s}}^{2}\right)}{\varepsilon_{\mathrm{s}}\left(\mathrm{n}_{\mathrm{s}}^{2}+2\right)^{2}}\right]
$$

$\mathrm{C}_{\mathrm{B}}$ is the actual concentration of the base, whereas $\mathrm{C}_{\mathrm{S}}$ and $\mathrm{C}_{\mathrm{S}}^{\circ}$ is the actual concentration of the solvent in the solution and pure state respectively. $S$ is referred to the solvent. So, one can write $D=\sum_{i} \mu_{i}^{2} C_{i}$. In studying hydrogen bond formation by a substance $B$ dissolved at a concentration $\mathrm{C}_{\mathrm{B}}$ in a non-polar solvent the following experimental function may be considered,

$$
\Omega_{\mathrm{B}}=\frac{\mathrm{D}}{\mathrm{C}_{\mathrm{B}}} \text {. }
$$

If the substance B exhibits self-association,

$$
\Omega_{\mathrm{B}}=\frac{\mu_{\mathrm{i}}^{2} \mathrm{C}_{\mathrm{i}}}{\mathrm{C}_{\mathrm{B}}}=<\mu_{\mathrm{i}}^{2} / \mathrm{i}>\text {. }
$$

When substances $A$ and $B$ are dissolved in a non-polar solvent at the formal concentrations $C_{A}$ and $C_{B}$, if these compounds form only hydrogen bonded complexes of 1:1 stoichiometry, one can write:

$$
\mathrm{C}_{\mathrm{A}}=\mathrm{C}_{\mathrm{a}}+\mathrm{C}_{\mathrm{ab}}=\mathrm{C}_{\mathrm{a}}\left(1+\mathrm{KC}_{\mathrm{b}}\right) \text { and } \mathrm{C}_{\mathrm{B}}=\mathrm{C}_{\mathrm{b}}+\mathrm{C}_{\mathrm{ab}}=\mathrm{C}_{\mathrm{b}}\left(1+\mathrm{KC}_{\mathrm{b}}\right)
$$

Here $C_{a}, C_{b}$ and $C_{a b}$ are the actual concentration of the entities and $K$ is the equilibrium constant for complex formation. Then,

$$
\mathrm{D}=\mu_{\mathrm{a}}^{2} \mathrm{C}_{\mathrm{a}}+\mu_{\mathrm{b}}^{2} \mathrm{C}_{\mathrm{b}}+\mu_{\mathrm{ab}}^{2} \mathrm{C}_{\mathrm{ab}}
$$

Dividing by $\mathrm{C}_{\mathrm{B}}$ and taking the equilibrium constant into account this can be written as:

$$
\mathrm{D}=\mu_{\mathrm{a}}^{2} \mathrm{C}_{\mathrm{a}}+\left(\mu_{\mathrm{ab}}^{2}-\mu_{\mathrm{b}}^{2}\right) \frac{1}{1+\left(\mathrm{KC}_{\mathrm{b}}\right)} \frac{\mathrm{C}_{\mathrm{A}}}{\mathrm{C}_{\mathrm{B}}}
$$

Consider the case where $K_{b}>>1$, this is obtained when $C_{B}-C_{A} \gg>K^{-1}$, under these circumstances, the equation (2) can be reduced to:

$$
\Omega_{\mathrm{b}}=\mu_{\mathrm{b}}^{2}+\left(\mu_{\mathrm{ab}}^{2}-\mu_{\mathrm{b}}^{2}\right) \frac{\mathrm{C}_{\mathrm{A}}}{\mathrm{C}_{\mathrm{B}}} .
$$

The plots may draw between $\Omega_{b}$ with $\mathrm{C}_{\mathrm{A}} / \mathrm{C}_{\mathrm{B}}$. From the plots obtained the dipole moment of the base and complexes.

\section{Dipolar increment $(\Delta \mu)$}

The dipole increment may be written as:

$$
\Delta \mu=\mu_{\mathrm{ab}}-\mu_{\mathrm{a}}-\mu_{\mathrm{b}} \text {. }
$$

Above equation can be used to the dipolar increment. The calculated values reported in the Table- 2 . This indicates that polarization interaction occurs from the proton donor and acceptor. The redistribution of the charges due to the dipole moment varies enormously. 


\section{Determination of Enthalpy changes during bond formation}

The relation between the enthalpy changes $\left(\Delta \mathrm{H}_{\mathrm{b}}\right)$ and dipolar increment $(\Delta \mu)$ is given by:

$$
\Delta \mu=\frac{\mathrm{A}\left(-\Delta \mathrm{H}_{\mathrm{b}}\right)+\left[\mathrm{B}+\mathrm{C}\left(-\Delta \mathrm{H}_{\mathrm{b}}\right)\right] \exp \left[\mathrm{A}_{1}+\mathrm{B}_{1}\left(-\Delta \mathrm{H}_{\mathrm{b}}\right)\right]}{1+\left[\mathrm{A}_{1}+\mathrm{B}_{1}\left(-\Delta \mathrm{H}_{\mathrm{b}}\right)\right.}
$$

The equation was tested for more than one hundred OH..O complexes including some OH..N complexes. The above equation may be modified for the calculation of $-\Delta \mathrm{H}_{\mathrm{b}}$ from the known $\Delta \mu$. If it is expressed in Debye and $-\Delta \mathrm{H}_{\mathrm{b}}$ in $\mathrm{KJmol}^{-1}$, the numerical values of the constants as follows:

For $\mathrm{OH} . . \mathrm{O}$ bond $\mathrm{A}=0.028, \mathrm{~A}_{1}=-6.5, \mathrm{~B}=3.20, \mathrm{~B}_{1}=0.085, \mathrm{C}=0.075$

For $\mathrm{OH} . . \mathrm{N}$ bond $\mathrm{A}=0.0074, \mathrm{~A}_{1}=-7.765, \mathrm{~B}=4.41, \mathrm{~B}_{1}=0.172 \mathrm{C}=0.045$.

The equations 1 to 9 were used find the complex dipole moment, the dipole moment of the base, dipolar increment and enthalpy changes during the bond formation and reported the Table- 1 to 2.

\section{RESULTS AND DISCUSSION}

The dielectric constant $(\varepsilon)$, refractive indices (n) and density $(\rho)$ of the ternary mixtures for the various concentrations of the alcohols (methanol, ethanol, propanol, and butanol ) with aniline concentration keeping constant results are reported in Table-1. Utilized the Huysken's method find the complex dipole moment from the experimental values. The dipolar increment finds from the relation (8) when the complex. From the complex dipole moment and dipole moment of the pure liquids used to find the dipolar increment also find the enthalpy changes from the dipolar increment reported in Table-2. The bond moments represented in Fig.-2 and evaluate the dipole moment of the cis and trans structure was presented in Table-2.The plots $\Omega_{\mathrm{B}}$ vs $\mathrm{C}_{\mathrm{A}} / \mathrm{C}_{\mathrm{B}}$ obtain a straight line with intercept $\mu_{\mathrm{b}}^{2}$ and slope $\left(\mu_{\mathrm{ab}}^{2}-\mu_{\mathrm{b}}^{2}\right)$. The appearance to higher order complexes $\mathrm{A}_{2} \mathrm{~B}, \mathrm{~A}_{3} \mathrm{~B}$ etc, generally provokes curvature of the line. The experimental quantity $\Omega_{b}$ is calculated for various concentrations such as $C_{A} / C_{B}$ value varying from 0.0 to 1.1 for each system. The plot of $\Omega_{b}$ versus $C_{A} / C_{B}$ for all the systems studied is drawn; the readings and plots are given in Table-1 and Fig.-1 to 4. The dipole moment of the complexes obtained by Huyskens method and dipole moment of the base are given in Table-2. It reveals that the dipole moment of the complexes determined is not equal to the sum of the magnitude of the dipole moment of the components A and B. A hydrogen bond can remain constant due to the electrons from the bond are shown by the theoretical calculations. In case of isomers, it can change the direction of dipolar increment for the various positions of rotation. The dipolar increment indicates the directions of the bonds. So it can reasonable to explain that the magnitude should reveal the nature of hydrogen bond.

Table-1: Dielectric constant $(\varepsilon)$, refractive index $(\mathrm{n})$ and density $\left(\mathrm{kg} / \mathrm{m}^{3}\right)$ mean square dipole $\operatorname{moment}\left(\Omega_{\mathrm{B}}\right)$ of various consternation of alcohols (alcohols $\left.\mathrm{C}_{\mathrm{B}} \mathrm{M}\right)-$ aniline $(0.5 \mathrm{M})$ at $301 \mathrm{~K}$

\begin{tabular}{c|c|c|c|c|c|c|c|c|c|c}
\hline $\mathrm{C}_{\mathrm{B}}$ & $\varepsilon$ & $n$ & $\rho$ & $\Omega_{\mathrm{B}}$ & $\mathrm{C}_{\mathrm{B}}$ & $\varepsilon$ & \multicolumn{5}{c|}{${ }^{2}$} & $\rho$ & $\Omega_{\mathrm{B}}$ \\
\hline \multicolumn{9}{c|}{ Methanol } \\
\hline 0.1 & 4.6 & 1.521 & 1.274 & 145.7 & 0.1 & 4.57 & 1.521 & 1.274 & 143.9 \\
\hline 0.2 & 4.75 & 1.52 & 1.265 & 77.5 & 0.2 & 4.7 & 1.52 & 1.265 & 76.0 \\
\hline 0.3 & 4.92 & 1.518 & 1.257 & 55.3 & 0.3 & 4.84 & 1.519 & 1.257 & 53.6 \\
\hline 0.4 & 5.08 & 1.517 & 1.248 & 44.0 & 0.4 & 4.98 & 1.518 & 1.248 & 42.4 \\
\hline 0.5 & 5.25 & 1.515 & 1.24 & 37.4 & 0.5 & 5.12 & 1.517 & 1.24 & 35.7 \\
\hline 0.6 & 5.42 & 1.514 & 1.232 & 32.9 & 0.6 & 5.26 & 1.516 & 1.232 & 31.2 \\
\hline 0.7 & 5.6 & 1.513 & 1.223 & 29.8 & 0.7 & 5.41 & 1.515 & 1.223 & 28.0 \\
\hline 0.8 & 5.78 & 1.511 & 1.215 & 27.5 & 0.8 & 5.56 & 1.514 & 1.215 & 25.7 \\
\hline
\end{tabular}


RASĀYAN J. Chem.

Vol. 10 | No. 4 |1247-1252 | October - December | 2017

\begin{tabular}{c|c|c|c|c|c|c|c|c|c}
\hline 0.9 & 5.97 & 1.51 & 1.207 & 25.7 & 0.9 & 5.71 & 1.513 & 1.207 & 23.9 \\
\hline 1 & 6.16 & 1.508 & 1.199 & 24.3 & 1 & 5.86 & 1.512 & 1.199 & 22.4 \\
\hline 1.1 & 6.35 & 1.507 & 1.191 & 23.2 & 1.1 & 6.02 & 1.511 & 1.191 & 21.2 \\
\hline \multicolumn{7}{|c}{ Propanol } \\
\hline 0.1 & 4.56 & 1.522 & 1.274 & 142.9 & 0.1 & 4.55 & 1.522 & 1.274 & 142.3 \\
\hline 0.2 & 4.67 & 1.521 & 1.265 & 75.0 & 0.2 & 4.66 & 1.521 & 1.265 & 74.7 \\
\hline 0.3 & 4.79 & 1.52 & 1.257 & 52.5 & 0.3 & 4.77 & 1.521 & 1.257 & 52.0 \\
\hline 0.4 & 4.92 & 1.519 & 1.248 & 41.4 & 0.4 & 4.88 & 1.52 & 1.248 & 40.7 \\
\hline 0.5 & 5.04 & 1.518 & 1.24 & 34.6 & 0.5 & 4.99 & 1.519 & 1.24 & 34.0 \\
\hline 0.6 & 5.16 & 1.518 & 1.232 & 30.0 & 0.6 & 5.11 & 1.519 & 1.232 & 29.5 \\
\hline 0.7 & 5.29 & 1.517 & 1.223 & 26.9 & 0.7 & 5.22 & 1.518 & 1.223 & 26.3 \\
\hline 0.8 & 5.42 & 1.516 & 1.215 & 24.6 & 0.8 & 5.34 & 1.517 & 1.215 & 23.9 \\
\hline 0.9 & 5.55 & 1.515 & 1.207 & 22.7 & 0.9 & 5.46 & 1.517 & 1.207 & 22.0 \\
\hline 1 & 5.69 & 1.514 & 1.199 & 21.3 & 1 & 5.59 & 1.516 & 1.199 & 20.6 \\
\hline 1.1 & 5.83 & 1.514 & 1.191 & 20.1 & 1.1 & 5.71 & 1.515 & 1.191 & 19.4 \\
\hline
\end{tabular}

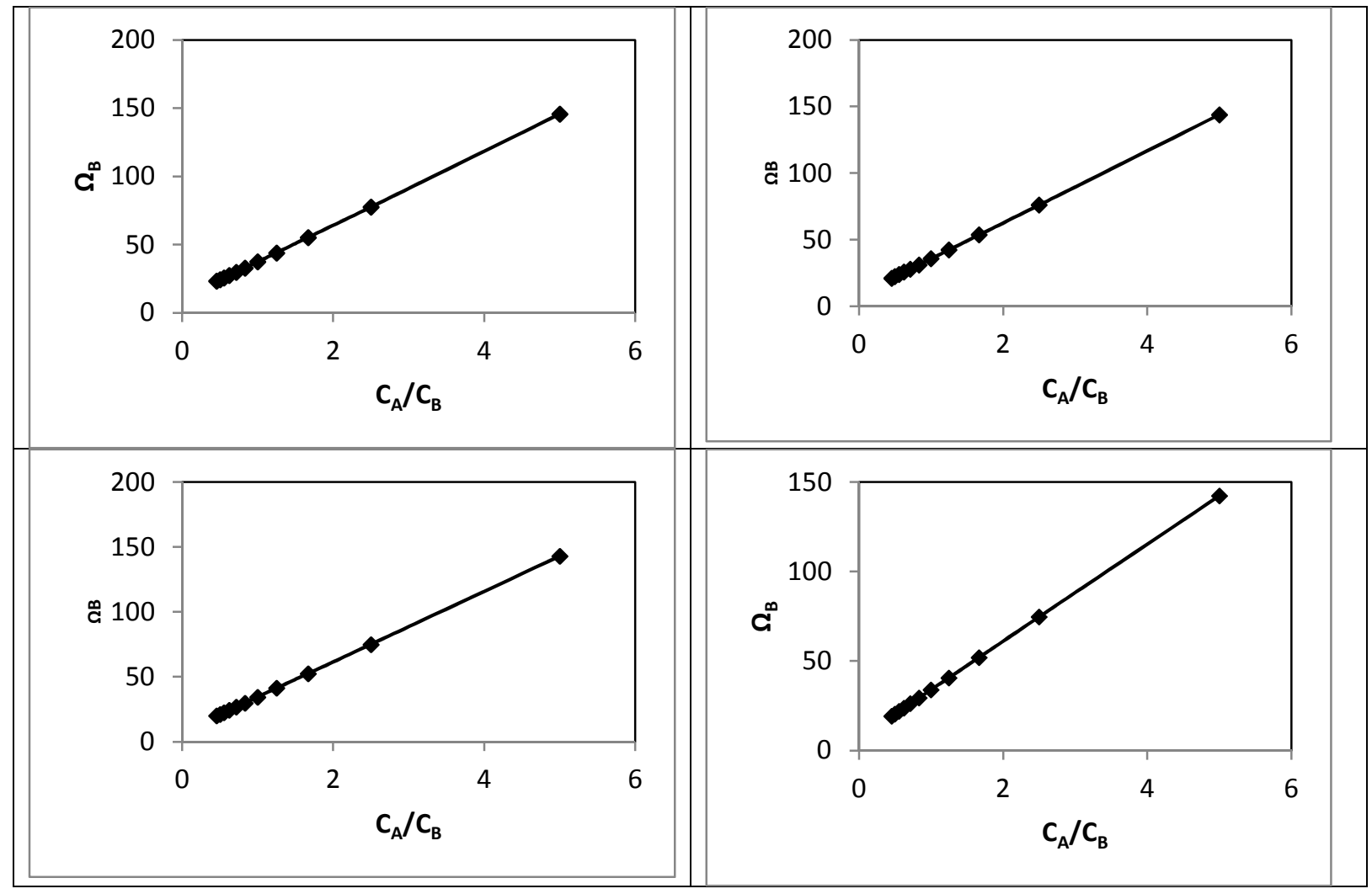

Fig.-1: Plots of $C_{A} / C_{B}$ with $\Omega_{B}$ of donor-acceptor complexes

Table-2: The dipole moment of the complex $\left(\mu_{a b}\right)$, cis $\left(\mu_{c i s}\right)$ and trans $\left(\mu_{\text {trans }}\right)$ complex, dipole increment $(\Delta \mu)$ and enthalpy changes $\left(\Delta H_{\mathrm{B}}\right)$

\begin{tabular}{l|c|c|r|r|r|r}
\hline Donor & Acceptor & $\mu_{a b}$ & $\mu_{c i s}$ & $\mu_{\text {trans }}$ & $\Delta \mu$ & $\Delta H_{\mathrm{B}}$ \\
\hline Methanol & & 5.24 & 6.11 & 7.44 & 1.49 & 5.364 \\
\hline Ethanol & & 5.15 & 5.95 & 7.26 & 1.44 & 5.184 \\
\hline Propanol & & 5.08 & 5.88 & 7.17 & 1.39 & 5.004 \\
\hline Butanol & & 5.01 & 5.80 & 7.08 & 1.34 & 4.824 \\
\hline
\end{tabular}


From the Table-2, the dipolar increment of all the systems less than $1.49 \mathrm{D}$. These indicates that not arising ionic structure due to small values $(<10 \mathrm{D})$. It may have the other type of interactions. The interaction may arise due to the electronics. Hence may be concluded that interaction due to polarization. ${ }^{16-20}$

\section{CONCLUSION}

For all the systems, the dipolar increment is small less than 2D. This is concluded that interaction arising due to the polarization and not to the other phenomena. ${ }^{21-24}$ The dipolar increment, enthalpy changes , dipole moment of cis and trans are reported in Table-2. The results are may be an interpretation of higher order complexes must prevail. The complexation of aniline not had broken the bonds of alcohol. The value of dipolar increment and enthalpy changes during bond formation indicate the order of complexes methanol $>$ ethanol $>$ propanol $>$ butanol, aniline as one of the acceptor components.

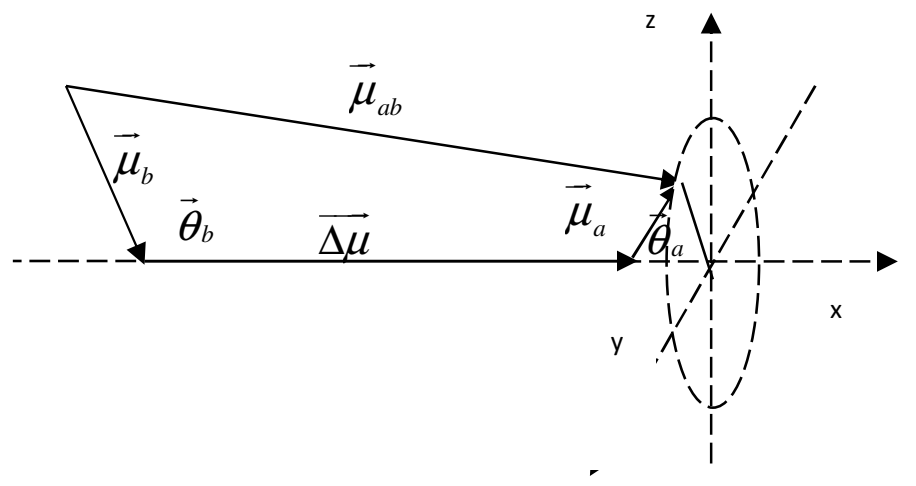

Fig.-2: Dipole moment $\mu_{\mathrm{a} .} \mu_{\mathrm{b}}$ and $\mu_{\mathrm{ab}}$ and $\Delta \mu$

The plots of $\Omega_{B} V_{s} C_{A} / C_{B}$ are a straight line and also dipolar increment is small . Hence it is supported the interactions mainly due to polarization only and it is not arising the other phenomena. From the Table- 2 , the dipole moment value of the trans structure is higher than cis structure, so trans structure is possible for the aniline - hydroxyl complexes.

\section{REFERENCES}

1. R. Anandhi and P.Krishnamurthi, Res. J. Pharm. Biol. Chem. Sci., 5(1), 650 (2014).

2. S. Balamuralikrishnan, and A.Uma Maheswari, J. Mol. Liq., 12, 419 (2006).

3. R.Anandhi and P. Krishnamurthi, J. Chem. Sci. Trans ., 4(3), 750 (2015).

4. M. Meenachi and P.Krishnamurthi , Rasayan J. Chem., 8(1), 98 (2015).

5. P. Maragathavel, K. Raju and P.Krishnamurthi , Rasayan J. Chem., 8(2), 227 (2015).

6. P.A.Thenmozhi1 and P.Krishnamurthi, Rasayan J. Chem., 8(1), 24 (2015).

7. R. Anandhi and P.Krishnamurthi, Rasayan J. Chem., 8(1), 109 (2015).

8. R. G. Jaiswal, and M. L. Maroti, RA J. App. Re.,3(2), 861 (2017)

9. S.S. Ubarhande,, A.S. Burghate, B.N. Berad and J.D. Turak, Rasayan J. Chem., 8(1), 109 (2015). 4(3), 585 (2015)

10. P.A. Thenmozhili , P. Krishnamurthi and H.B. Ramalingam, W. J. P.R., 6(3), 1368 (2017).

11. M. Meenach, P. Krishnamurthi , C.Shanthi , and H.B. Ramalingam, Der Phar. Sinica, 7(1) , 1 (2016).

12. M. Subnramanian and T. Thennappan, Indian J. Pure \& Appl. Phys., 39, 417 (2001).

13. T. Thenappan and M. Subramanian, Mater. Sci. Eng., 86B, 7 (2001).

14. A. Singh, R. Misra, J.P. Shukla and M.C. Sexana, Indian J. Pure Appl. Pys., 21, 228 (1983).

15. P. Krishnamurthi, H.B. Ramalingam, and A. Sudha Der Chem. Sinica, 7(2), 86( 2016)

16. P. Krishnamurthi , H.B. Ramalingam and K. Raju, Arch Appl Sci., Res. 7(11), 5 (2015)

17. M. Meenachi M and P. Krishnamurthi, Int. J. Res. Phar. Bio. Sci., 3(4) , 1719 (2012). 
18. P. Krishnamurthi and S. Balamuralikrishnan, J. Con. Eng. Tech. Sci., 1, 23 (2009).

19. P. Krishnamurthi and S.Balamuralikrishnan, Asian J. Chem., 22 (7), 5144 (2010).

20. P. Krishnamurthi and S. Balamuralikrishnan, Asian J. Chem., 22(7), 5139, (2010).

21. P. Krishnamurthi and T. Vasavi , I. J. Phar. and Bio. Research, 4(1), 126 (2013).

22. P. Krishnamurthi and P.A. Thenmozhili, I. J. Pharm. Chem. Res , 4(11), 4671. (2012).

23. P. Krishnamurthi and P.A. Thenmozhili, I. J. Pharm. Chem . Res., 4(11), 4677 (2012).

24. M. Malathi, R. Sabesan and S. Krishnan, J. Mol. Liq., 109, 11 (2004).

[RJC-1709/2017] 